\title{
Comparison between Laying Hen Performance in the Cage System and the Deep Litter System on a Diet Free from Animal Protein
}

\author{
E. VOSLÁR̆OVÁ ${ }^{1}$, Z. HANZÁLEK ${ }^{3}$, V. VEČEREK ${ }^{1}$, E. STRAKOVÁ ${ }^{2}$, P. SUCHÝ ${ }^{2}$ \\ ${ }^{1}$ Department of Public Veterinary Medicine and Toxicology \\ ${ }^{2}$ Department of Nutrition, Animal Husbandry and Animal Hygiene \\ University of Veterinary and Pharmaceutical Sciences Brno, Czech Republic \\ ${ }^{3}$ Veterinary Clinic, Hradec Králové, Czech Republic
}

Received March 29, 2005

Accepted March 16, 2006

\begin{abstract}
Voslářová E., Z. Hanzálek, V. Večerek, E. Straková, P. Suchý: Comparison between Laying Hen Performance in the Cage System and the Deep Litter System on a Diet Free from Animal Protein. Acta Vet. Brno 2006, 75: 219-225.

Battery cage systems for housing laying hens are being replaced by alternative systems including the deep litter system. At the same time, the substitution of meat and bone meal by vegetable matter in poultry feed mixtures is sought in the nutrition of laying hens. In the experiment, we compared the performance of laying hens of the ISA BROWN hybrid in both the cage system and the deep litter system, on a diet with the meat and bone meal content replaced by vegetable feeds (based on lupin). In the first group, 36 laying hens were kept in the deep litter system; in the second group, 36 laying hens were kept in cages. Over the period of nine months, the number of eggs laid, their weight, shell quality, the clinical state of the laying hens and incidence of their mortality were monitored daily. We found that in the cage system a higher number of eggs was obtained; a lower mean egg weight $(p<0.01)$; a higher number of eggs per hen per day $(p<0.01)$; a higher egg mass weight per hen per day $(p<0.01)$. There was a higher number of cracked eggs of the total number of eggs laid $(p<0.01)$, the number of membranous eggs of the total number of eggs laid did not differ $(p>0.05)$, and the number of laying hens which died was lower $(p<0.05)$ in comparison with the deep litter system. The results of the experiment demonstrate that, with the substitution of meat and bone meal by vegetable matter in the feed mixtures for laying hens, there are differences between the performance of laying hens from the deep litter system as compared to the laying hens from the cage system. The deep litter system better meets the requirements for the welfare of laying hens; however, it provides a lower yield.
\end{abstract}

Rearing technology, vegetable feeds, number of eggs, egg weight, cracked eggs, mortality

The traditional battery cage systems for the rearing of laying hens are being replaced by alternative systems to promote and increase laying hen welfare. Savory (2004) states that Council Directive 1999/74/EC laying down minimum standards for the protection of laying hens abolishes battery cage systems within the European Union from 2012. This Directive responds to public opinion requirements concerning the welfare of laying hens. However, scientific knowledge, in evaluating the battery cage system for laying hen rearing particularly in regard to production indicators, is not so unequivocal. This is due to the fact that the alternative systems often include higher risks to both the production and the health of laying hens. This is especially applicable to non-cage systems. The main issues requiring control in larger group floor housing are: parasitic disorders; the outbreak and spread of cannibalistic pecking; increased feed intake; misplaced eggs; the catching of spent hens; and air quality (Tau s on 2005).

Duncan (2001) cites the advantages of the battery cage system. He regards as positive the low incidence of disease, the low incidence of social friction, and the absence of problems resulting from litter. As disadvantages, he cites: the lack of physical space for laying hens; the lack of space for daily activities and nesting; the absence of opportunities for dust-bathing; the higher incidence of foot lesions. 
Petermann (2003) found an increased incidence of mortality in alternative housing systems. De B oer and Cornelis sen (2002) consider the battery cage system, particularly from the perspective of production and some health indicators, to be more beneficial than the aviary systems.

Changes relating to the diet of laying hens are being promoted in the present practice of rearing laying hens. The animal protein in poultry feed, provided by meat and bone meal, is being replaced by vegetable protein from selected vegetable products. Suchý et al. (2002) and Malá et al. (2004) described the replacement of animal protein by vegetable protein based on lupin in broilers. Hadorn et al. (2000) focused on the replacement of animal protein in the diet of laying hens.

The yield of laying hens, particularly in the number of eggs, can also be influenced by the incidence of mortality in laying hens. Petermann (2003) claims that the incidence of mortality in the deep litter systems, is high. Alternative systems, despite their benefit for welfare, thus encounter problems which remain unresolved.

Taylor and Hurnik (1996) compared the long-term performance of laying hens in the battery cage systems and aviary systems. They did not detect any evidential differences in egg weight, in the total daily egg production per hen, in the production of egg mass per hen per month and in the number of cracked eggs.

Vits et al. (2005) analysed the effect of furnished cages and two different small group systems on the production traits and egg quality traits of laying hens. The authors reported that the housing system and group size influenced egg production per hen, egg weight and the number of cracked eggs.

Taus on et al. (1999) studied the number of cracked eggs in the battery cage system and the aviary system. They discovered that the number of cracked eggs was lower in the aviary system in comparison with the battery cage system.

Abrahamsson and Taus on (1998) monitored the incidence of mortality in the rearing of laying hens. In the aviary system, they discovered a significant variation from 4.0 to $20.9 \%$ and explained this as the consequence of unpredictable cases of cannibalism. Sommer and Vasicek (2000) cite mortality in free-range poultry flocks at the level of 0 to $32 \%$. Taus on et al. (1999) monitored the incidence of mortality in laying hens kept in cages and in laying hens kept in the aviary system. In laying hens in the aviary system, they detected mortality at the level of 21 to $27 \%$, caused mainly in result of bacterial infections due to the pecking at naked skin by more aggressive laying hens. In the battery cage system, the mortality level did not exceed 7\%. Similarly, Weitzenburger et al. (2005) reported that the incidence of mortality was greater in floor-reared laying hens than in the laying hens reared in conventional cages.

The aim of our study was to compare the performance of laying hens of ISA BROWN hybrid in both the cage and deep litter systems, on a diet with the meat and bone meal content replaced by vegetable feeds (based on lupin).

\section{Materials and Methods}

A comparison was made between the egg yields of laying hens kept in two rearing technologies: the deep litter system and the cage system, on the same level of nutrition without animal protein. 72 ISA BROWN hybrid laying hens were divided into two groups at the age of 16 weeks. The first group of 36 laying hens was kept in the deep litter system; the second group was kept in conventional cages for laying hens. The microclimate and lighting conditions for rearing followed the technological standard for the rearing of this hybrid. Feed mixtures N1 and N2, in which animal protein was replaced by vegetable protein based on lupin, were supplied ad libitum using automatic feeders. The composition of the feed mixtures N1 and N2 is provided in Table 1. Water was supplied ad libitum using automatic drinkers.

The experimental investigation, along with the collection of eggs, commenced at the 19th/20th week. The laying hens were observed for nine months (from 20 to 56 weeks of age). The number of eggs laid and their weight was monitored during this period on a daily basis. From the data collected, the mean egg weight, the mean number of eggs laid per hen per day, and the mean egg-mass production per hen per day were calculated monthly and then for the 
Table 1. Component composition of feed mixtures (\%)

\begin{tabular}{|l|c|c|}
\hline Components & $\begin{array}{c}\text { N1 } \\
\text { Layers up to age } \\
32 \text { weeks }\end{array}$ & $\begin{array}{c}\text { N2 } \\
\text { Layers from age } \\
\text { of 32 weeks onwards }\end{array}$ \\
\hline Wheat & 25.68 & 31.49 \\
\hline Corn & 30.00 & 35.00 \\
\hline Soybean extracted meal & 20.30 & 15.50 \\
\hline Proenergol (lupin) & 10.00 & 6.00 \\
\hline Soybean oil & 3.25 & 1.50 \\
\hline L- lysine monohydrochloride & 0.14 & 0.15 \\
\hline Hydrosyanalog of methionine & 0.26 & 0.20 \\
\hline L - threonine & 0.05 & 0.06 \\
\hline Calcium carbonate coarse-grained & 4.00 & 3.50 \\
\hline Calcium carbonate & 4.20 & 4.90 \\
\hline Monocalcium phosphate & 1.50 & 1.15 \\
\hline Sodium chloride & 0.42 & 0.35 \\
\hline Aminovitan SK & 0.20 & 0.20 \\
\hline
\end{tabular}

entire period under review. In addition, the shell quality of eggs was observed, in particular the number of eggs that were cracked and the number that were membranous. From these data, the relative number of cracked and membranous eggs out of the total number of eggs was calculated monthly and then for the entire period under review.

The health status of the laying hens was monitored by clinical examination and the incidence of mortality in laying hens was recorded in the group in the deep litter system and in the group in the cage system over the entire period. The cause of death was determined by pathological-anatomical dissection.

The results were statistically processed using the statistical program Unistat, version 5.1. The mean values in the deep litter system group and in the cage system group were compared by an unpaired $t$-test; frequencies were compared using the $\chi^{2}$ test.

\section{Results}

In the deep litter system and in the cage system, the number and mean weight of eggs were monitored monthly and over the entire period under review. The results are shown in Table 2. The table shows that the number of eggs was higher in the cage system, and that the egg weight was higher $(\mathrm{p}<0.01)$ in the deep litter system.

Table 2. Number and mean egg weight in the deep litter system and in the cage system

\begin{tabular}{|l|c|c|c|c|c|c|c|}
\hline & \multicolumn{3}{|c|}{ Deep litter } & \multicolumn{4}{c|}{ Cage } \\
\cline { 2 - 8 } Period & $\mathrm{n}$ & $\begin{array}{c}\mathrm{x} \\
(\mathrm{g})\end{array}$ & $\begin{array}{c}\mathrm{sd} \\
(\mathrm{g})\end{array}$ & $\mathrm{n}$ & $\begin{array}{c}\mathrm{x} \\
(\mathrm{g})\end{array}$ & $\begin{array}{c}\mathrm{sd} \\
(\mathrm{g})\end{array}$ & $p$ \\
\hline 1st month & 490 & 51.72 & 5.49 & 596 & 51.76 & 6.16 & 0.893 \\
\hline 2nd month & 954 & 60.45 & 6.47 & 958 & 58.09 & 5.52 & $0.000^{* *}$ \\
\hline 3rd month & 844 & 62.83 & 6.01 & 938 & 59.85 & 5.23 & $0.000^{* *}$ \\
\hline 4th month & 840 & 63.49 & 5.38 & 933 & 62.49 & 5.41 & $0.000^{* *}$ \\
\hline 5th month & 690 & 64.84 & 5.05 & 846 & 63.61 & 5.30 & $0.000^{* *}$ \\
\hline 6th month & 404 & 66.13 & 5.04 & 823 & 63.73 & 5.48 & $0.000^{* *}$ \\
\hline 7th month & 353 & 67.43 & 4.59 & 810 & 65.04 & 5.30 & $0.000^{* *}$ \\
\hline 8th month & 343 & 66.28 & 4.72 & 760 & 66.40 & 5.42 & 0.700 \\
\hline 9th month & 294 & 65.49 & 4.91 & 715 & 65.96 & 4.89 & 0.165 \\
\hline Total & 5212 & 62.67 & 6.87 & 7379 & 62.00 & 6.74 & $0.000^{* *}$ \\
\hline
\end{tabular}

$\mathrm{n}=$ number of eggs, $\mathrm{x}=$ arithmetic mean, $\mathrm{sd}=$ standard deviation, $p=$ statistical significance,

** = statistically highly significant $(p<0.01)$

Calculation: $\mathrm{x}=$ sum of all egg weights / number of all eggs 
Table 3. Mean egg number per hen per day in the deep litter system and in the cage system

\begin{tabular}{|l|c|c|c|c|c|}
\hline \multirow{2}{*}{ Period } & \multicolumn{2}{|c|}{ Deep litter } & \multicolumn{2}{c|}{ Cage } & \\
\hline 1st month & $\mathrm{x}$ & 0.297 & 0.591 & 0.233 & 0.147 \\
\hline 2nd month & 0.486 & 0.052 & 0.950 & 0.059 & 0.792 \\
\hline 3rd month & 0.946 & 0.149 & 0.931 & 0.074 & $0.005^{* *}$ \\
\hline 4th month & 0.837 & 0.185 & 0.926 & 0.081 & $0.021^{*}$ \\
\hline 5th month & 0.833 & 0.205 & 0.865 & 0.137 & $0.000^{* *}$ \\
\hline 6th month & 0.685 & 0.154 & 0.919 & 0.100 & $0.000^{* *}$ \\
\hline 7th month & 0.463 & 0.149 & 0.904 & 0.080 & $0.000^{* *}$ \\
\hline 8th month & 0.491 & 0.100 & 0.848 & 0.087 & $0.000^{* *}$ \\
\hline 9th month & 0.490 & 0.202 & 0.798 & 0.093 & $0.000^{* *}$ \\
\hline Total & 0.420 & 0.258 & 0.859 & 0.155 & $0.000^{* *}$ \\
\hline
\end{tabular}

$\mathrm{x}=$ arithmetic mean, $\mathrm{sd}=$ standard deviation, $p=$ statistical significance, $*=(p<0.05),{ }^{*} *=(p<0.01)$

Calculation: $\mathrm{x}=$ number of eggs $/$ sum of all daily numbers of hens in individual month

The results of mean egg numbers per hen per day are shown in Table 3 . The table shows that the mean egg number per hen per day was significantly higher in the cage system.

On the basis of these data, the mean egg mass weight per hen per day was calculated. The results are shown in Table 4 . The table shows that the mean egg mass weight per hen per day was significantly higher in the cage system.

Table 4. Mean egg mass weight per hen per day in the deep litter system and in the cage system

\begin{tabular}{|l|c|c|c|c|c|}
\hline \multirow{2}{*}{ Period } & \multicolumn{2}{|c|}{ Deep litter } & \multicolumn{2}{c|}{ Cage } & \multirow{2}{*}{$p$} \\
\cline { 2 - 5 } & $\begin{array}{c}\mathrm{x} \\
(\mathrm{g})\end{array}$ & $\begin{array}{c}\mathrm{sd} \\
(\mathrm{g})\end{array}$ & $\begin{array}{c}\mathrm{x} \\
(\mathrm{g})\end{array}$ & $\begin{array}{c}\mathrm{sd} \\
(\mathrm{g})\end{array}$ & 0.176 \\
\hline 1st month & 25.14 & 16.295 & 30.61 & 13.411 & $0.045^{*}$ \\
\hline 2nd month & 57.21 & 3.596 & 55.21 & 3.709 & 0.109 \\
\hline 3rd month & 52.61 & 9.023 & 55.70 & 4.361 & $0.048^{*}$ \\
\hline 4th month & 52.91 & 11.981 & 57.84 & 4.745 & $0.001^{* *}$ \\
\hline 5th month & 44.38 & 13.169 & 54.98 & 8.822 & $0.000^{* *}$ \\
\hline 6th month & 30.63 & 10.004 & 58.53 & 6.141 & $0.000^{* *}$ \\
\hline 7th month & 33.14 & 9.850 & 58.80 & 5.345 & $0.000^{* *}$ \\
\hline 8th month & 32.48 & 6.723 & 56.32 & 5.850 & $0.000^{* *}$ \\
\hline 9th month & 27.51 & 13.283 & 52.64 & 6.311 & $0.000^{* *}$ \\
\hline Total & 39.56 & 15.893 & 53.40 & 10.834 & 0.834 \\
\hline
\end{tabular}

$\mathrm{x}=$ arithmetic mean, $\mathrm{sd}=$ standard deviation, $p=$ statistical significance, $*=(p<0.05),{ }^{*} *=(p<0.01)$

Calculation: $\mathrm{x}=$ number of eggs * mean egg weight $/$ sum of all daily numbers of hens in individual month

The results showing the number of cracked and membranous eggs out of the total number of eggs laid are shown in Table 5. The table shows that the number of cracked eggs was found to be higher $(\mathrm{p}<0.01)$ in the cage system and the number of membranous eggs was higher in the cage system; however, this latter difference was not regarded as statistically significant.

The health status of the laying hens was observed by means of a clinical examination. No clinical change was recorded in the health status of the laying hens during the monitoring period. The incidence of mortality in the laying hens was recorded over the whole period in the deep litter system group and in the cage system group. The cause of death was established on the basis of pathological-anatomical dissection. There were cases of sudden death 
Table 5. Number of cracked and membranous eggs in the deep litter system and in the cage system out of the total number of eggs laid

\begin{tabular}{|l|c|c|c|c|c|c|}
\hline & \multicolumn{3}{|c|}{ Cracked } & \multicolumn{3}{|c|}{ Membranous } \\
\cline { 2 - 7 } & $\begin{array}{c}\text { Deep } \\
\text { litter } \\
(\%)\end{array}$ & $\begin{array}{c}\text { Cage } \\
(\%)\end{array}$ & $p$ & $\begin{array}{c}\text { Deep } \\
\text { litter } \\
(\%)\end{array}$ & $\begin{array}{c}\text { Cage } \\
(\%)\end{array}$ & $p$ \\
\hline 1st month & 3.06 & 5.03 & 0.105 & 1.02 & 1.68 & 0.356 \\
\hline 2nd month & 1.47 & 8.25 & $0.000^{* *}$ & 0.84 & 0.94 & 0.814 \\
\hline 3rd month & 2.84 & 8.42 & $0.000^{* *}$ & 0.00 & 0.21 & 0.180 \\
\hline 4th month & 0.95 & 5.79 & $0.000^{* *}$ & 0.12 & 0.43 & 0.220 \\
\hline 5th month & 0.58 & 4.49 & $0.000^{* *}$ & 0.00 & 0.24 & 0.201 \\
\hline 6th month & 1.73 & 3.28 & 0.121 & 0.00 & 0.12 & 0.483 \\
\hline 7th month & 1.70 & 6.17 & $0.001^{* *}$ & 0.00 & 0.00 & 1.000 \\
\hline 8th month & 1.46 & 3.42 & 0.068 & 0.00 & 0.00 & 1.000 \\
\hline 9th month & 2.72 & 3.92 & 0.352 & 0.00 & 0.00 & 1.000 \\
\hline Total & 1.75 & 5.57 & $0.000^{* *}$ & 0.27 & 0.38 & 0.288 \\
\hline
\end{tabular}

$p=$ statistical significance, $* *=(p<0.01)$

resulting from cannibalism. The number of dead laying hens per month and for the entire period under review is shown in Table 6. The results show a manifestation of cannibalism concentrated in the fifth and sixth months of the period under review. A statistically significantly higher incidence of mortality was detected in the deep litter system.

Table 6. Number of dead laying hens in the deep litter system and in the cage system

\begin{tabular}{|l|c|c|c|}
\hline Period & Deep litter & Cage & $p$ \\
\hline 1st month & 0 & 0 & 1.000 \\
\hline 2nd month & 0 & 0 & 1.000 \\
\hline 3rd month & 0 & 0 & 1.000 \\
\hline 4th month & 0 & 0 & 1.000 \\
\hline 5th month & 0 & 4 & $0.040^{*}$ \\
\hline 6th month & 10 & 0 & $0.001^{* *}$ \\
\hline 7th month & 1 & 0 & 0.263 \\
\hline 8th month & 0 & 0 & 1.000 \\
\hline 9th month & 0 & 0 & 1.000 \\
\hline Mean & 1.2 & 0.4 & - \\
\hline Total & 11 & 4 & $0.042^{*}$ \\
\hline
\end{tabular}

$p=$ statistical significance, $*=(p<0.05), * *=(p<0.01)$

\section{Discussion}

The housing of laying hens intended for egg production is changing at present; the traditional battery cage systems are being replaced by alternative systems, among which the deep litter systems are of great importance. Savory (2004) claims that this change is influenced rather by public opinion than by scientific knowledge. Duncan (2001) summarizes the advantages and disadvantages of the cage systems. Other authors, e.g. De Boer and Cornelissen (2002), Petermann (2003), Tauson (2005) etc. also document in their studies that the replacement of traditional battery cage systems by alternative systems does not always have an unambiguously positive impact on egg production, the health of laying hens and the incidence of mortality in laying hens. 
Changes in the keeping of laying hens are also being brought about by another tendency: the replacement of animal protein in the diet of laying hens by vegetable protein. The results of experiments focusing on the replacement of meat and bone meal by vegetable feed in laying hens were described by Hadorn et al. (2000), and then in broilers by Suchý et al. (2002) and Malá et al. (2004).

In our study we investigated the impact on egg production of both developmental trends, i.e. the replacement of the battery cage system by the deep litter system and at the same time the change in the diet of laying hens, in which meat and bone meal was replaced by vegetable feeds based on lupin.

We discovered that the number of eggs obtained from laying hens in the deep litter system was lower than the number obtained from laying hens in the cage system. This was due, in part, to some eggs being mislaid outside the nests in the deep litter system. In addition, mislaid eggs are often damaged and broken and the number of laying hens is also decreased as a consequence of the higher incidence of mortality in the deep litter system. This effect has been manifested since the $3^{\text {rd }}$ month. We can thus declare in accord with the opinion of Petermann (2003) that the alternative system has its problems, which are reflected in the number of eggs obtained from laying hens.

In our experiment, egg weight was found to be greater in the deep litter system than in the cage system. Similarly, Vits et al. (2005) reported a higher egg weight in floor-reared laying hens. Thus, we cannot endorse the results published by Taylor and Hurnik (1996), who, when comparing the performance of laying hens in battery cages and in aviaries, did not discover any substantial differences in egg weight.

The mean number of eggs per hen per day was found to be higher in the cage system, as well as the mean egg mass weight per hen per day. Taylor and Hurnik (1996), however, did not find any difference between the cage systems and the aviary systems in respect to these indicators.

In our experiment, the number of cracked eggs and membranous eggs was detected higher in the cage system. These results are in keeping with the findings of Tau son et al. (1999), who found a higher proportion of cracked eggs in the cage systems than in the floor ones. Taylor and Hurnik (1996), however, did not detect these differences in the incidence of shell-damaged eggs.

Manifestations of cannibalism were concentrated in the fifth and sixth months of the period under study and a higher incidence of mortality was recorded in the deep litter systems. The results confirm a higher incidence of mortality in the alternative systems and accord with the results published by the authors cited. Weitzenburger et al. (2005) reported a higher incidence of mortality in floor-reared laying hens than in laying hens reared in conventional cages. The authors indicated different types of cannibalism as the most common cause of death in laying hens. Abrahams son and Tauson (1998) also refer to the high incidence of mortality in aviary systems, namely at a level of $4.0-20.9 \%$, and Sommer and Vasicek (2000) at a level of 0 - 32\%. Taus on et al. (1999) claim a mortality rate for aviary systems at a level of $21-27 \%$ and for battery cage systems at a level of $7 \%$. In our experiment, the incidence of mortality corresponded to the level from the sources quoted; it was at $30.6 \%$ in the deep litter system and $11.1 \%$ in the cage system.

The results of the experiment prove that, in the diet with the substitution of meat and bone meal by vegetable matter in feed mixtures for laying hens, there are differences in the yield of laying hens in both the deep litter system and in the cage system. The deep litter system better meets the requirements for the welfare of laying hens; however, it is accompanied by a lower yield. 


\section{Porovnání užitkovosti nosnic v klecovém chovu a v chovu na hluboké podestýlce při výživě bez živočišné bílkoviny}

Bateriové klecové chovy nosnic jsou nahrazovány chovy alternativními, mezi něž se řadí také voliérový chov nosnic na hluboké podestýlce. Současně se pro chovy nosnic hledá ve výživě vegetabilní náhrada za masokostní moučky v krmných směsích. V experimentu jsme porovnávali užitkovost nosnic ISA BROWN z klecového chovu a chovu voliérového na hluboké podestýlce, a to při výživě obsahující náhradu masokostní moučky vegetabilními krmivy (na bázi lupiny). V první skupině bylo 36 nosnic chovaných ve voliéře na hluboké podestýlce, $v$ druhé skupině bylo 36 nosnic chovaných v klecích. Po dobu devíti měsíců byl denně sledován počet snesených vajec, jejich hmotnost, kvalita skořápky, klinický stav nosnic a úhyny nosnic. Zjistili jsme, že v klecovém chovu byl vyšší počet získaných vajec, nižší průměrná hmotnost vajec $(p<0,01)$, vyšší počet vajec na jednu slepici a na jeden den $(p<0,01)$, vyšší hmotnost vaječné hmoty na jednu slepici a na jeden den $(p<0,01)$, vyšší počet křapovitých vajec $\mathrm{z}$ celkového počtu snesených vajec $(p<0,01)$, nelišil se počet blanitých vajec z celkového počtu snesených vajec $(p>0,05)$, nižší byl počet uhynulých nosnic $(p<0,05)$ ve srovnání s voliérovým chovem nosnic na hluboké podestýlce. Výsledky experimentu prokazují, že při výživě nosnic s vegetabilní náhradou masokostních mouček v krmných směsích pro nosnice existují rozdíly v užitkovosti nosnic z voliérového chovu na hluboké podestýlce a nosnic z klecového chovu. Voliérový chov splňuje lépe požadavky na welfare nosnic, avšak je provázen nižší užitkovostí.

\section{Acknowledgements}

The work was realized with the support of MSM Project No. 6215712402 "Veterinary Aspects of Foodstuff Safety and Quality".

\section{References}

ABRAHAMSSON P, TAUSON R 1998: Performance and egg quality of laying hens in an aviary system. J Appl Poult Res 7: 225-232

DE BOER IJM, CORNELISSEN AMG 2002: A method using sustainability indicators to compare conventional and animal-friendly egg production systems. Poult Sci 81: 173-181

DUNCAN IJH 2001: The pros and cons of cages. Worlds Poult Sci J 57: 381-390

HADORN R, GLOOR A, WIEDMER H 2000: Effect of the exclusion of synthetic amino acids and potentially GMO-protein sources in vegetable diets for laying hens. Arch Geflugelkd 64: 75-81

MALÁ S, SLEZÁČKOVÁ I, STRAKOVÁ E, SUCHÝ P, VEČEREK V 2004: Plant-based diets containing Casalts of fatty acids and their influence on performance, carcass characteristics, and health status of broiler chickens. Acta Vet Brno 73: 321-328

PETERMANN S 2003: Laying hens in alternative housing systems - practical experiences. Dtsch Tierarztl Wochenschr 110: 220-224

SAVORY CJ 2004: Laying hen welfare standards: a classic case of power to the people. Anim Welf 13 (Suppl): S153-S158

SOMMER F, VASICEK L 2000: Management and state of health in free-range poultry flocks. Wien Tierarz Monats 87: 202-212

SUCHÝ P, STRAKOVÁ E, VEČEREK V, SLEZÁČKOVÁ I 2002: Replacement of animal origin feed by plant origin feed in the diet of broiler chickens. Czech J Anim Sci 47: 365-373

TAUSON R 2005: Management and housing systems for layers - effects on welfare and production. Worlds Poult Sci J 61: 477- 490

TAUSON R, WAHLSTROM A, ABRAHAMSSON P 1999: Effect of two floor housing systems and cages on health, production, and fear response in layers. J Appl Poult Res 8: 152-159

TAYLOR AA, HURNIK JF 1996: The long-term productivity of hens housed in battery cages and an aviary. Poult Sci 75: 47-51

VITS A, WEITZENBURGER D, HAMANN H, DISTL O 2005: Influence of different small-group-systems on production traits, egg quality and bone breaking strength of laying hens. 1st communication: Production traits and egg quality. Zuchtungskunde 77: 303-323

WEITZENBURGER D, VITS A, HAMANN H, DISTL O 2005: Effect of furnished small group housing systems and furnished cages on mortality and causes of death in two layer strains. Br Poult Sci 46: 553-559 